\title{
Corrigendum
}

\section{Employee brand equity: Scale development and validation}

Ceridwyn King, Debra Grace and Daniel C. Funk

Journal of Brand Management (2013) 20, 350-354. doi:10.1057/bm.2012.60; published online 4 January 2013

Correction to: Journal of Brand Management (2012) 19(4): 268-288. doi:10.1057/bm.2012.44

The authors wish to apologise that in the following Tables, under the Brand Consistent Behaviour section, BCB4 incorrect text was used. The corrected tables are given here. 
Table 2: EBE scale - Research phase two: purification (exploratory) $(N=86)$

\begin{tabular}{|c|c|c|c|c|c|c|c|}
\hline & & \multirow[t]{2}{*}{ Mean (SD) } & \multicolumn{3}{|c|}{ Factor loadings } & \multirow[t]{2}{*}{ VE } & \multirow[t]{2}{*}{$E / V$} \\
\hline & & & 1 & 2 & 3 & & \\
\hline \multicolumn{8}{|c|}{ Brand endorsement: } \\
\hline BEI7 & $\begin{array}{l}\text { I say positive things about the } \\
\text { organisation (brand) I work for to } \\
\text { others }\end{array}$ & $5.01(1.48)$ & 0.96 & - & - & - & - \\
\hline $\mathrm{BE} 18$ & $\begin{array}{l}\text { I would recommend the organisation } \\
\text { (brand) I work for to someone who } \\
\text { seeks my advice }\end{array}$ & $5.01(1.43)$ & 0.86 & - & - & - & - \\
\hline $\mathrm{BEI}$ & $\begin{array}{l}\text { I enjoy talking about the organisation } \\
\text { (brand) I work for to others }\end{array}$ & $4.74(\mathrm{I} .44)$ & 0.77 & - & - & - & - \\
\hline BE20 & $\begin{array}{l}\text { I talk positively about the organisation } \\
\text { (brand) I work for to others }\end{array}$ & $4.82(1.37)$ & 0.83 & - & - & $47.68 \%$ & 5.72 \\
\hline \multicolumn{8}{|c|}{ Brand consistent behaviour: } \\
\hline BCB2 & $\begin{array}{l}\text { I demonstrate behaviours that are } \\
\text { consistent with the brand promise of } \\
\text { the organisation I work for }\end{array}$ & $5.65(1.07)$ & - & 0.88 & - & - & - \\
\hline $\mathrm{BCB} 3$ & $\begin{array}{l}\text { I consider the impact on my } \\
\text { organisation's brand before } \\
\text { communicating or taking action in } \\
\text { any situation }\end{array}$ & $5.12(1.30)$ & - & 0.84 & - & - & - \\
\hline BCB4 & $\begin{array}{l}\text { I show extra initiative to ensure my } \\
\text { behaviour remains consistent with } \\
\text { the brand promise of the organisation } \\
\text { I work for }\end{array}$ & $5.48(1.29)$ & - & 0.71 & - & - & - \\
\hline $\mathrm{BCB7}$ & $\begin{array}{l}\text { I am always interested to learn about my } \\
\text { organisation's brand and what it means } \\
\text { to me in my role }\end{array}$ & $5.11(1.29)$ & - & 0.81 & - & $17.01 \%$ & 2.04 \\
\hline \multicolumn{8}{|c|}{ Brand allegiance: } \\
\hline $\mathrm{BA} / 3$ & $\begin{array}{l}\text { I plan to be with the organisation (brand) } \\
\text { I work for, for awhile }\end{array}$ & $4.50(1.70)$ & - & - & 0.67 & - & - \\
\hline $\mathrm{BAI} 4$ & $\begin{array}{l}\text { I plan to be with the organisation (brand) } \\
\text { I work for } 5 \text { years from now }\end{array}$ & $2.65(1.82)$ & - & - & 0.83 & - & - \\
\hline BAI5 & $\begin{array}{l}\text { I would turn down an offer from } \\
\text { another organisation (brand) if it came } \\
\text { tomorrow }\end{array}$ & $3.40(1.70)$ & - & - & 0.82 & - & - \\
\hline \multirow[t]{3}{*}{ BAI 6} & $\begin{array}{l}\text { I plan to stay with the organisation } \\
\text { (brand) I work for }\end{array}$ & $3.84(1.84)$ & - & - & 0.84 & $8.49 \%$ & 1.01 \\
\hline & & & & & \multicolumn{2}{|c|}{ OverallVE } & $73.18 \%$ \\
\hline & & & & \multicolumn{3}{|c|}{ Overall Cronbach's $\alpha$} & 0.89 \\
\hline
\end{tabular}

Abbreviations: $\mathrm{VE}=$ Variance Explained; $\mathrm{SD}=\mathrm{Standard}$ Deviation; $\mathrm{E} / \mathrm{V}=$ Eigen value. 
Table 3: EBE scale - Research phase 3: Purification (confirmation) $N=273$

\begin{tabular}{|c|c|c|c|c|c|c|c|c|c|}
\hline & & & & & & $\begin{array}{l}\text { Standardisec } \\
\text { loadings }\end{array}$ & \multicolumn{3}{|c|}{ Fit statistics } \\
\hline \multicolumn{10}{|c|}{ Brand endorsement: } \\
\hline $\mathrm{BEI7}$ & \multicolumn{5}{|c|}{$\begin{array}{l}\text { I say positive things about the organisation (brand) I work for } \\
\text { to others }\end{array}$} & 0.83 & \multicolumn{2}{|c|}{-} & - \\
\hline BEI8 & \multicolumn{5}{|c|}{$\begin{array}{l}\text { I would recommend the organisation (brand) I work for to } \\
\text { someone who seeks my advice }\end{array}$} & 0.77 & \multicolumn{2}{|c|}{-} & - \\
\hline $\mathrm{BE} 19$ & \multicolumn{5}{|c|}{$\begin{array}{l}\text { I enjoy talking about the organisation (brand) I work for to } \\
\text { others }\end{array}$} & 0.69 & \multicolumn{2}{|c|}{ - } & - \\
\hline BE20 & \multicolumn{5}{|c|}{$\begin{array}{l}\text { I talk positively about the organisation (brand) I work for to } \\
\text { others }\end{array}$} & 0.87 & \multicolumn{2}{|c|}{-} & - \\
\hline \multicolumn{10}{|c|}{ Brand allegiance: } \\
\hline BAI3 & \multicolumn{5}{|c|}{ I plan to be with the organisation (brand) I work for, for awhile } & 0.73 & \multicolumn{2}{|c|}{$\chi^{2}$} & 87.71 \\
\hline BAI4 & \multicolumn{5}{|c|}{$\begin{array}{l}\text { I plan to be with the organisation (brand) I work for } 5 \text { years } \\
\text { from now }\end{array}$} & 0.68 & \multicolumn{2}{|c|}{$\begin{array}{l}\text { Degrees of } \\
\text { freedom }\end{array}$} & 41 \\
\hline BAI5 & \multicolumn{5}{|c|}{$\begin{array}{l}\text { I would turn down an offer from another organisation (brand) if } \\
\text { it came tomorrow }\end{array}$} & 0.65 & \multicolumn{2}{|c|}{$P$-value } & 0.000 \\
\hline BAI6 & \multicolumn{5}{|c|}{ I plan to stay with the organisation (brand) I work for } & 0.82 & \multicolumn{2}{|c|}{ GFI } & 0.95 \\
\hline \multicolumn{6}{|c|}{ Brand consistent behaviour: } & & \multicolumn{2}{|c|}{ NFI } & 0.94 \\
\hline $\mathrm{BCB} 2$ & \multicolumn{5}{|c|}{$\begin{array}{l}\text { I demonstrate behaviours that are consistent with the brand } \\
\text { promise of the organisation I work for }\end{array}$} & 0.71 & \multicolumn{2}{|c|}{ TLI } & 0.95 \\
\hline ВCB3 & \multicolumn{5}{|c|}{$\begin{array}{l}\text { I consider the impact on my organisation's brand before } \\
\text { communicating or taking action in any situation }\end{array}$} & 0.72 & \multicolumn{2}{|c|}{ CFI } & 0.96 \\
\hline \multirow[t]{3}{*}{ BCB4 } & \multirow{3}{*}{\multicolumn{5}{|c|}{$\begin{array}{l}\text { I show extra initiative to ensure my behaviour remains } \\
\text { consistent with the brand promise of the organisation } \\
\text { I work for }\end{array}$}} & 0.82 & \multicolumn{2}{|c|}{ RMSEA } & 0.06 \\
\hline & & & & & & & \multirow{2}{*}{\multicolumn{2}{|c|}{$\begin{array}{l}\text { Average variance } \\
\text { ext } \\
\text { Composite } \\
\text { reliability }\end{array}$}} & $57.3 \%$ \\
\hline & & & & & & & & & 0.93 \\
\hline \multicolumn{2}{|c|}{ Model comparisons (dimensionality) } & $\chi^{2}$ & $D F$ & $P$-value & GFI & $\mathrm{NFI}$ & $T L I$ & CFI & RMSEA \\
\hline \multicolumn{2}{|c|}{ One-factor model } & 475.5 & 44 & 0.000 & 0.72 & 0.65 & 0.59 & 0.67 & 0.19 \\
\hline Two-factc & r model & 295.2 & 43 & 0.000 & 0.80 & 0.78 & 0.75 & 0.81 & 0.15 \\
\hline Three-fac & tor model & 87.7 & 41 & 0.000 & 0.95 & 0.94 & 0.95 & 0.96 & 0.06 \\
\hline Discriminc & nt validity tests & & & & & & & & \\
\hline Construct & pairs & $\begin{array}{r}\text { Uncor } \\
m\end{array}$ & ined & $\begin{array}{r}\text { Const } \\
m c\end{array}$ & & $\begin{array}{r}\text { Mo } \\
\text { differe }\end{array}$ & el & $\begin{array}{r}\text { Discri } \\
\text { vali }\end{array}$ & $\begin{array}{l}\text { minant } \\
\text { dity? }\end{array}$ \\
\hline & & $\chi^{2}$ & $D F$ & $\chi^{2}$ & $D F$ & $\chi^{2}$ & $D F$ & & \\
\hline Brand en & torsement/brand allegiance & 37.8 & 19 & 43.7 & 20 & 5.9 & I & & es \\
\hline $\begin{array}{l}\text { Brand en } \\
\text { behavic }\end{array}$ & $\begin{array}{l}\text { Horsement/brand consistent } \\
\text { ur }\end{array}$ & 36.4 & 13 & 57.0 & 14 & 20.6 & I & & es \\
\hline $\begin{array}{l}\text { Brand all } \\
\text { behavic }\end{array}$ & $\begin{array}{l}\text { giance/brand consistent } \\
\text { ur }\end{array}$ & 15.3 & 13 & 63.0 & 14 & 47.7 & I & & es \\
\hline
\end{tabular}


Table 4: EBE scale - research phase 4: validation $(N=37 \mathrm{I})$

\begin{tabular}{llll}
\hline & \multicolumn{2}{c}{ Factor loadings } & AVE CR \\
\cline { 2 - 3 } & 1 & 2 \\
\end{tabular}

EBE scale (three factors) $\chi^{2}=\mid 22.2, \mathrm{DF}=4 \mathrm{I}, P=0.00, \mathrm{GFI} 0.95, \mathrm{NFI} 0.96, \mathrm{TLI} 0.97, \mathrm{CFI} 0.98$ and RMSEA 0.07

Brand endorsement:

BEI7 I say positive things about the organisation (brand) I work for to others

BEI8 I would recommend the organisation (brand) I work for to someone who seeks my advice

BEI9 I enjoy talking about the organisation (brand) I work for to others

BE20 I talk positively about the organisation (brand) I work for to others

Brand allegiance:

BAI3 I plan to be with the organisation (brand) I work for, for awhile

BAI4 I plan to be with the organisation (brand) I work for 5 years from now

BAI5 I would turn down an offer from another organisation (brand) if it came tomorrow

BAI6 I plan to stay with the organisation (brand) I work for

Brand consistent behaviour:

BCB2 I demonstrate behaviours that are consistent with the brand promise of the organisation I work for

BCB3 I consider the impact on my organisation's brand before communicating or taking action in any situation

BCB4 I show extra initiative to ensure that my behaviour remains consistent with the brand promise of the organisation I work for

Role clarity (two factors) $\chi^{2}=100.0, \mathrm{DF}=13, P=0.00, \mathrm{GFI} 0.93, \mathrm{NFI} 0.95, \mathrm{TLI} 0.93, \mathrm{CFI} 0.96$ and RMSEA 0.13

Generic role clarity:

RCGI I know how I should behave while I am on the job

RCG2 I know how I am expected to handle unusual problems and situations while on the job

RCG3 I know exactly what output is expected of me on the job

RCG4 I know what I am expected to achieve in my job

$\begin{array}{lllll}0.91 & - & - & - & - \\ 0.91 & - & - & - & - \\ 0.86 & - & - & - & - \\ 0.92 & - & - & - & - \\ & & & & - \\ - & 0.91 & - & - & - \\ - & 0.90 & - & - & - \\ - & 0.86 & - & - & - \\ - & 0.92 & - & - & - \\ - & - & 0.68 & - & - \\ - & - & 0.76 & - & - \\ - & - & 0.83 & 0.75 & 0.93\end{array}$

Brand role clarity:

RCB5 Information about my organisation's brand improved $m y$ basic understanding of my job

RCB6 I understand what is expected of me because I have information about my organisation's brand

RCB7 I know how to make specific decisions for my job because I have information about my organisation's brand

$\begin{array}{lllll}0.83 & - & - & - & - \\ 0.82 & - & - & - & - \\ 0.85 & - & - & - & - \\ 0.83 & - & - & - & - \\ - & 0.90 & - & - & - \\ - & 0.94 & - & - & - \\ - & 0.91 & - & 0.76 & 0.95\end{array}$

Brand commitment (one factor) $\chi^{2}=17.39, \mathrm{DF}=5, \mathrm{P}=0.00, \mathrm{GFI} 0.98, \mathrm{NFI} 0.98, \mathrm{TLI} 0.98, \mathrm{CFI} 0.99$ and RMSEA 0.07

\begin{tabular}{|c|c|c|c|c|c|c|}
\hline $\mathrm{BCl}$ & I am proud to be a part of the organisation I work for & 0.89 & - & - & - & - \\
\hline $\mathrm{BC} 2$ & I really care about the fate of the organisation I work for & 0.88 & - & - & - & - \\
\hline $\mathrm{BC} 3$ & $\begin{array}{l}\text { My values are similar to those of the organisation } \\
\text { I work for }\end{array}$ & 0.85 & - & - & - & - \\
\hline BC4 & $\begin{array}{l}\text { I am willing to put in extra effort beyond what is } \\
\text { expected to make the organisation I work for } \\
\text { successful }\end{array}$ & 0.86 & - & - & - & - \\
\hline BC5 & I feel like I really fit in where I work & 0.78 & - & - & 0.73 & 0.92 \\
\hline
\end{tabular}

Abbreviations: $\mathrm{AVE}=$ Average Variance Extracted; $C R=$ Composite Reliability. 
The author also wishes to apologise that in the Scale Replication section on page 281 the data in the penultimate sentence was incorrect. The corrected sentence is given below.

The fit for the measurement mode was good with $\chi^{2}=122.2, d f=41, P=0.00$, GFI 0.95, NFI 0.96, TLI 0.97, CFI 0.98 and RMSEA 0.07. 